\title{
Comparison of Lim1 expression in embryos of frogs with different modes of reproduction
}

\author{
MICHAEL VENEGAS-FERRÍN ${ }^{1}$, NORIHIRO SUDOU ${ }^{2}$, MASANORI TAIRA ${ }^{2}$ and EUGENIA M. DEL PINO*,1 \\ ${ }^{1}$ Escuela de Ciencias Biológicas, Pontificia Universidad Católica del Ecuador, Quito, Ecuador and \\ ${ }^{2}$ Department of Biological Sciences, Graduate School of Science, University of Tokyo, Bunkyo-ku, Tokyo, Japan
}

\begin{abstract}
A polyclonal antibody was used to detect the expression of the homeodomain protein Lim1 (Lhx1) in embryos of Xenopus laevis, Engystomops randi, Colostethus machalilla and Gastrotheca riobambae. These frogs belong to four separate families, and have differences in their modes of reproduction and developmental rates. The expression of Lim 1 in embryos of these frogs resembled the $X$. laevis expression pattern. Thus, the dorsal blastopore lip, axial mesoderm, pronephros and certain cells of the central nervous system were Lim1-positive in embryos of all frogs. There were, however, time differences; thus, in the mid-gastrula of the rapidly developing embryos of $X$. laevis and $E$. randi, the Lim 1 protein was simultaneously detected in the prechordal plate (head organizer) and notochord (trunk organizer). In contrast, only the prechordal plate was Lim1-positive during gastrulation in the slow developing embryos of $C$. machalilla. The notochord elongated and became Lim1-positive after closure of the blastopore in $\boldsymbol{C}$. machalilla and $\boldsymbol{G}$. riobambae embryos. The prechordal plate of $G$. riobambae embryos could not be clearly detected, as the Lim1-signal remained around the blastopore during gastrulation. These observations indicate that the timing of gene expression at the dorsal blastopore lip in embryos of slow developing frogs differs from that of $X$. laevis. Moreover, the comparison shows that the developmental processes of the head and trunk organizers are basically separable and become dissociated in embryos of the slow developing frog, C. machalilla.
\end{abstract}

KEY WORDS: organizer, brachyury, Colostethus machalilla, Engystomops randi, Gastrotheca riobambae

\section{Introduction}

The dorsal blastopore lip of amphibian embryos, which is the Spemann-Mangold organizer, expresses specific genes, and initiates the development of dorsal axial structures (reviewed in Niehrs, 2004; de Robertis, 2006). The organizer has been divided into head, trunk, and tail organizers, according to the inductive properties of the various regions (reviewed in Saxén, 1989; Niehrs, 2004). One of the organizer genes is Xlim1 (also known as Xenopus $L h \times 1$ ), and its ectopic expression in the ventral blastopore lip of the Xenopus laevis gastrula produces duplication of the dorsal axis (Taira et al., 1992, 1994b). The gene sequence of Lim1 and its expression patterns at the mRNA, and protein levels are highly conserved among vertebrates (Dawid et al., 1998; Hobert and Westphal, 2000; Karavanov et al., 1996; del Pino et al., 2007).

In $X$. laevis embryos, $X \lim 1$ is expressed in the entire axial mesoderm of the gastrula and neurula (Taira et al., 1992, 1994a). The axial mesoderm derives from mesoderm that involutes along the dorsal midline, and consists of the prechordal plate, also known as head mesoderm, and the notochord, or mesoderm of the trunk (reviewed in Saxén, 1989). In the early gastrula, Xlim1 is additionally expressed in the lateral and ventral regions of the prospective mesoderm (Taira et al., 1992, 1994a). In contrast with $X \lim 1$, other genes are expressed either in the prechordal plate, or in the notochord. Thus, the homeobox genes goosecoid (gsc) and orthodenticle (Otx2) are expressed in the prechordal plate, and Brachyury (Bra) is expressed in the notochord of $X$. laevis embryos (Cho et al., 1991; Smith et al., 1991; Blitz and Cho, 1995; Pannese et al., 1995).

\footnotetext{
Abbreviations used in this paper: Bra, Brachyury; ce, convergence and extension; cns, central nervous system; pcp, planar cell polarity pathway; st, stage.
}

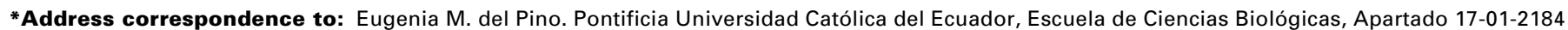
Avenida 12 de Octubre 1076 y Roca, Quito, Ecuador. Fax: +593-2-299-1687. e-mail: edelpino@puce.edu.ec
}

Supplementary Material for this paper (an MP3 audio podcast) is available at: http://dx.doi.org/10.1387/ijdb.092870mv 
Fig. 1. Specificity of anti-Xlim1. (A) Immunoblot analysis. Lanes 1 through 3 are in vitro translated products, and lanes 4 and 5 are embryonic lysates. Lane 2, Xlim1DNK is the N-terminal LIM domain-deleted construct, Xlim14NK (Karavanovet al., 1996). (B) Whole mount preparation of the $\mathrm{G}$. riobambae notochord. The rostral region is oriented towards the top. (C) Higher magnification of the Lim 1 signal observed in B. (C') Nuclear staining of the image shown in (C). There is quenching of fluorescence in the Lim 1-positive nuclei. Three Lim1-positive nuclei are indicated by arrows and a Lim1-negative nucleus by arrowheads in $\left(C, C^{\prime}\right)$. In this and the following figures, letters and numbers in the upper right hand corner indicate species and developmental stage. Cm, C. machalilla; Er, E. randi; Gr, G. riobambae; and $X I, X$. laevis. Abbreviations: $n$, notochord. Scale bars: $200 \mu \mathrm{m}(B) ; 25 \mu \mathrm{m}$ (C$\left.C^{\prime}\right)$.

An important developmental difference among frogs is the onset of dorsal ce movements in early embryos. In the rapidly developing embryos of $X$. laevis, ce begins in the mid-gastrula, and generates the concomitant elongation of the archenteron, notochord, and neural plate (Keller, 1975, 1976; Keller and Shook, 2004). The notochord similarly elongates in the mid gastrula of the leiuperid frog Engystomops randi, suggesting that in this frog ce begins during gastrulation, as in $X$. laevis. (del Pino et al., 2007). In contrast, the movements of ce begin once the blastopore has been closed in embryos of the frogs Gastrotheca riobambae and Colostethus machalilla, as detected by the expression of the protein Brachyury (Bra) in the notochord (del Pino, 1996; Benítez and del Pino, 2002; del Pino et al., 2007; Moya et al., 2007). In the absence of ce, cells that involute during gastru-
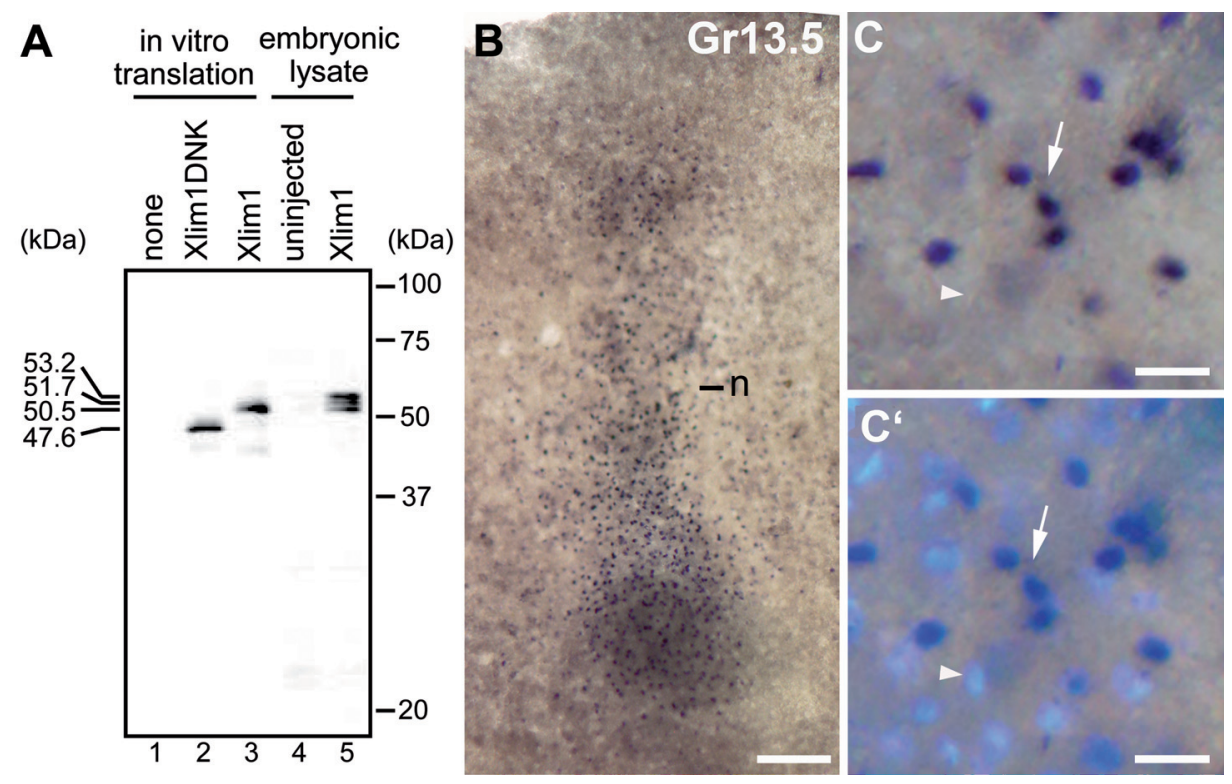

lation remain in the blastopore lip. As a consequence, the blastopore lip enlarges, and forms a thick circumblastoporal collar (cbc) around the closed blastopore of these slow developing frogs (del Pino and Elinson, 1983; Moya et al., 2007). Our understanding of the Spemann-Mangold organizer may be enhanced by the analysis of organizer genes in frogs with delayed elongation of the notochord.

Embryos of four different frogs were immunostained with a polyclonal antibody against the C-terminal region of the homeoprotein Xlim1. This antibody was previously used to detect the dorsal side in the early gastrula of $G$. riobambae, and the notochord and pronephros in embryos of other frogs (del Pino et al., 2007). Embryos of the following frogs were analyzed: The marsupial frog $G$. riobambae (Hemiphractidae), the poison-arrow
Fig. 2. Lim1 in the dorsal blastopore lip. In situ hybridization against Xlim1 mRNA is shown in (A); the remaining embryos were immunostained against Lim1 protein. (A,B) Early gastrulae of $\mathrm{X}$. laevis. (A) $\mathrm{X} \lim 1 \mathrm{~m} R \mathrm{NA}$ expression. (B) The dorsal blastopore lip in sagittal view reveals the internal Lim1 protein signal. (C,D) Gastrulae of E. randi. (C) Surface Lim1 protein signal in the dorsal blastopore lip. (D) The dorsal blastopore lip in sagittal view. The dark line in the middle of the image is due to unspecific staining of the blastocoel floor. (E,F) Early gastrulae of C. machalilla. (E) The surface Lim1-signal is visible in the dorsal blastopore lip, and in a belt around the blastopore. (F) The dorsal blastopore lip in sagittal view reveals the internal signal. (G,H) Mid gastrulae of G. riobambae. (G) Lim1 signal at st 12 occurs in a belt around the blastopore with a strong dorsal expression. (H) The blastopore of a st 12 embryo in sagittal view. A higher density of Lim1-positive nuclei were detected in the dorsal blastopore lip in comparison with the ventral lip. Abbreviations: dl, dorsal lip; vl, ventral lip; yp, yolk plug. Scale bars: $200 \mu \mathrm{m}(A, E, G, H) ; 100 \mu \mathrm{m}(B, C, D, F)$.

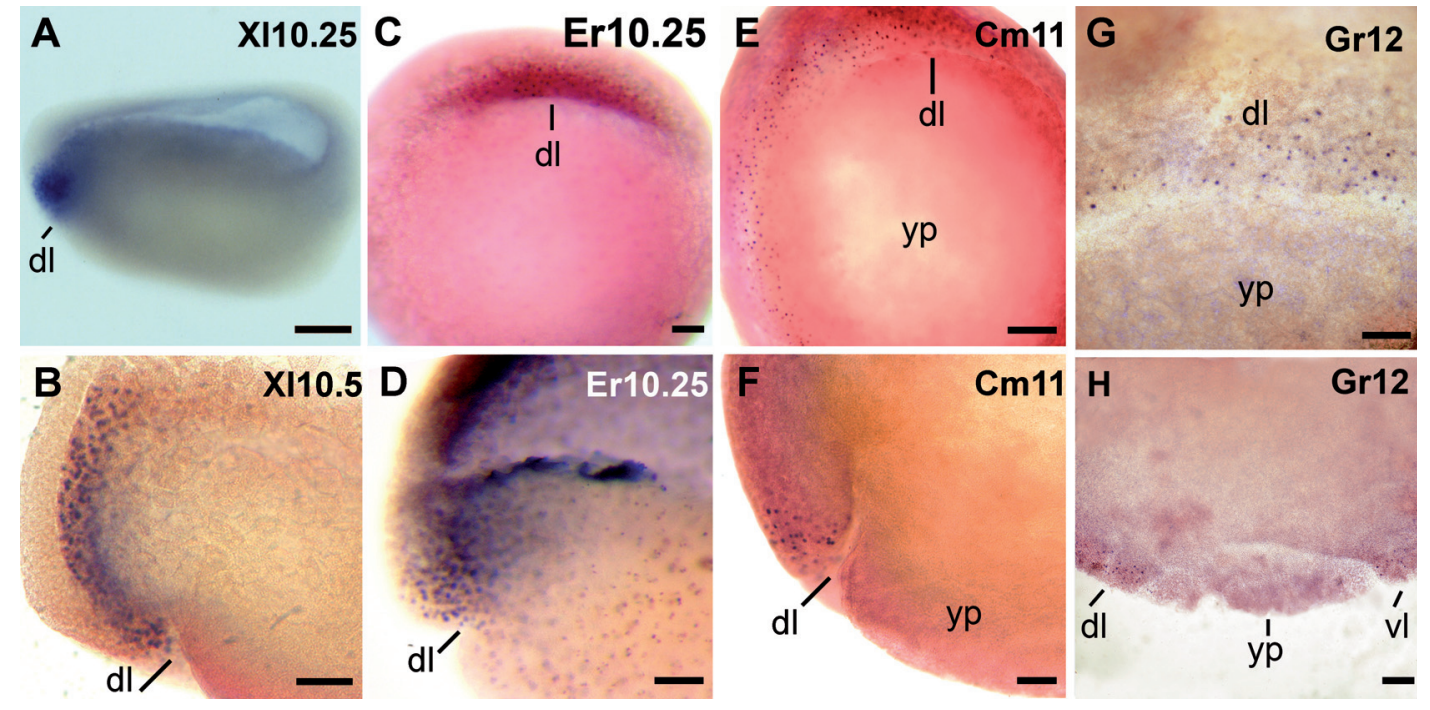


frog C. machalilla (Dendrobatidae), also known as Epipedobates machalilla (Grant et al., 2006), the foam-nesting frog Engystomops randi (Leiuperidae), and the aquatic frog $X$. laevis (Pipidae). These frogs differ in their reproductive modes, and rates of development. Thus, embryos of the marsupial frog, G. riobambae, develop very slowly, protected inside the dorsal pouch of the mother (del Pino, 1996). The embryos of the dendrobatid, $C$. machalilla, develop in terrestrial nests, and have an intermediate developmental rate, in comparison with $X$. laevis and $G$. riobambae embryos (del Pino et al., 2004). In contrast, the embryos of the leiuperid frog, $E$. randi, which are enclosed in a floating nest of foam, develop almost as fast as the $X$. laevis embryos (del Pino et al., 2007; Romero-Carvajal et al., 2009). The time required from fertilization to the end of gastrulation is 14 days in G. riobambae, 4 days in $C$. machalilla, 24 hours in $E$. randi, and 14 hours in $X$. laevis (Nieuwkoop and Faber, 1994; del Pino, 1996; del Pino et al., 2004, 2007). The comparative base line for our work is the molecular understanding of gastrulation and development in $X$. laevis (reviewed in de Robertis, 2006).

\section{Results}

\section{The specificity of the anti-Lim1 antibody}

Anti-Lim1 was produced against the highly conserved Cterminal region of the homeodomain protein Xlim1 from $X$. laevis. Immunoblot analysis was performed with in vitro translated products and embryonic lysates (Fig 1A). Electrophoretic separation of these proteins by SDS-PAGE showed that the apparent molecular masses of in vitro-translated Xlim1, and the $\mathrm{N}$-terminal Lim domain-deleted construct, Xlim1 $1 \mathrm{NK}$ (Karavanov et al., 1996) were higher than the calculated molecular masses: $50.5 \mathrm{kDa}$ versus $44,933.97 \mathrm{Da}$ for the wild type, and $46.4 \mathrm{kDa}$ versus 37,918.82 Da for Xlim1 $\Delta$ NK (Fig1A, lanes 2,3). The difference of apparent molecular masses of the wild type and $\mathrm{Xlim} 1 \Delta \mathrm{NK}(4.1$ $\mathrm{kDa})$ did not correspond to that of the calculated masses $(7,015.15$ Da), implying that both Lim domain A and the other part of Xlim1 protein affect its electrophoretic migration. Embryonic lysates showed three immunoreacted bands (Fig. 1A, lane 5), the lowest of which corresponds to the in vitro translated product of Xlim1 $(50.5 \mathrm{kDa})$. The sizes of the other two bands are 51.7 and 53.2 $\mathrm{kDa}$. The differences of these bands are 1.2 and $1.5 \mathrm{kDa}$, which are much smaller than the sizes of ubiquitin and SUMO, implying that other type of modifications, such as phosphorylation and methylation, may occur for the Xlim1 protein in the embryo. The presence of these three bands has also been shown in a previous study (Karavanov et al., 1996). Although we could not detect a clear band(s) of the endogenous Xlim1 protein in uninjected embryos (Fig.1A, lane 4), the data showed that the antibodies specifically recognize the Xlim1 protein that is synthesized with an in vitro translated system, or in embryos injected with Xlim1 mRNA (Fig. 1A, lanes 3,5). Moreover, our antibody labeled nuclei strongly in whole embryos of $X$. laevis, and other frogs (del Pino et al., 2007).

A late gastrula of $G$. riobambae was immunostained for Lim1 to detect the location of the Lim1 signal in embryonic tissues. After immunostaining, the embryonic disk was dissected and counterstained with the fluorescent nuclear dye, Hoechst 33258. We observed that nuclei of the recently formed notochord were Lim1- positive (Fig. 1B). When observed with fluorescence optics, the purple pigment of NBT/BCIP color reaction quenched the fluorescence of Hoechst 33258 in Lim1-positive nuclei. In contrast, nuclei that did not contain Lim1 protein were brightly fluorescent (Fig. $1 \mathrm{C}, \mathrm{C}^{\prime}$ ). Therefore, this antibody recognized the Lim1 protein distributed in cell nuclei of the G. riobambae notochord. It has been demonstrated previously that Lim1 is a transcription factor detected in cell nuclei (Karavanov et al., 1996).

\section{Lim1 protein in the dorsal blastopore lip}

In the dorsal region of stage (st) 10.25 embryos of $X$. laevis, Lim1 mRNA was detected in surface and deep cells (Fig. 2A). Similarly, the protein Lim1 was detected in surface and deep nuclei of the $X$. laevis dorsal blastopore lip (Fig. 2B). In addition, the prospective lateral and ventral mesoderm were Lim1-positive (not shown). A similar pattern was observed in the embryos of other frogs (Fig. $2 \mathrm{C}-\mathrm{H}$ ). There was, however, variation in the expression pattern, as mostly deep cells were Lim1-positive in embryos of $X$. laevis (Fig. $2 \mathrm{~B}$ ) and $\mathrm{G}$. riobambae (Fig. $2 \mathrm{G}, \mathrm{H}$ ), whereas surface and deep signals were detected in $E$. randi (Fig. 2 C,D) and C. machalilla embryos (Fig. 2 E,F). In addition, the first detection of Lim1 varied among frogs. The protein Lim1 was detected at st 10.25 in E. randi (Fig. 2 C,D), and at st 10 in G. riobambae embryos (not shown) In $C$. machalilla embryos, in contrast, the protein Lim1 was first detected at st 11 (Fig. 2 E,F).

In st 10 embryos of $G$. riobambae, before formation of the
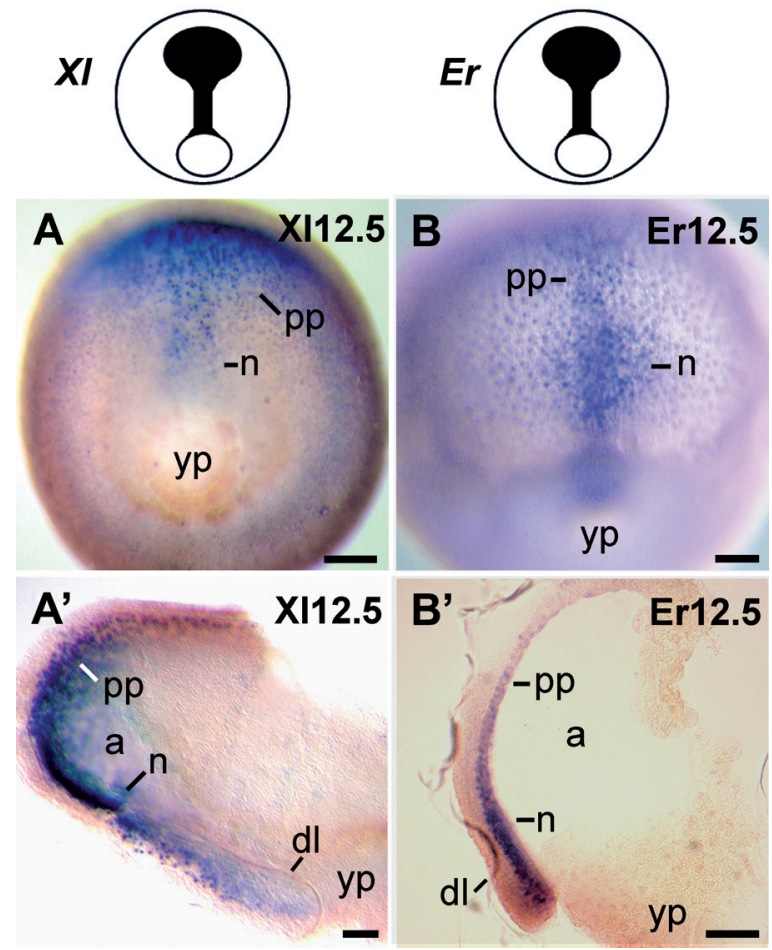

Fig. 3. The notochord and prechordal plate in rapidly developing embryos. (A, $\left.\mathbf{A}^{\prime}\right)$ Mid-gastrulae of $\mathrm{X}$. laevis. (A) Whole mount preparation. ( $\left.\mathbf{A}^{\prime}\right)$ The notochord and prechordal plate in sagittal view. (B, $\left.\mathbf{B}^{\prime}\right)$ Midgastrulae of $\mathrm{E}$. randi. (B) Whole mount preparation. (B') The notochord and prechordal plate in sagittal view. The drawings outline, in black, the Lim1-signal. Abbreviations: a, archenteron; dl, dorsal lip; n, notochord; pp, prechordal plate; yp, yolk plug. Scale bars: $200 \mu \mathrm{m}(A) ; 100 \mu \mathrm{m}\left(A^{\prime}, B, B^{\prime}\right)$ 


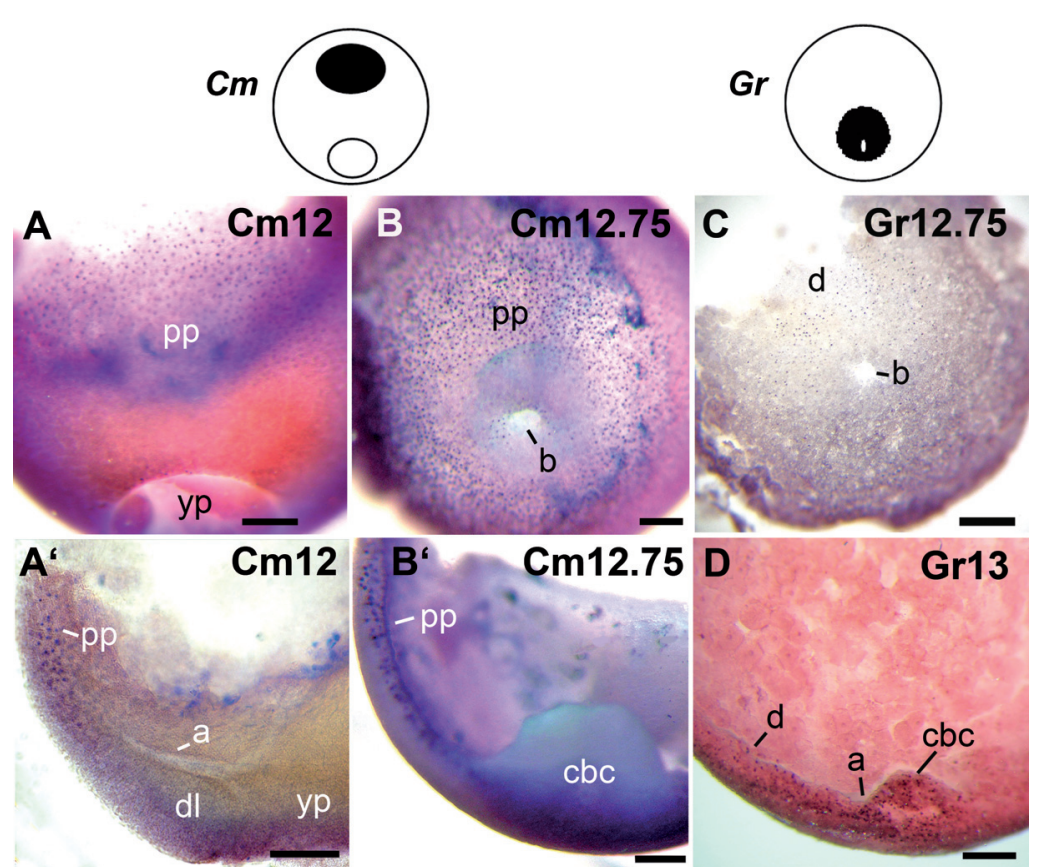

Fig. 4 (Above). The prechordal plate in slow developing embryos. ( $\left.A, B^{\prime}\right)$ Gastrulae of C. machalilla. (A) Mid-gastrula in whole mount. (A') Sagittal section of a mid-gastrula. (B) Late-gastrula in whole mount. (B') Sagittal section of a lategastrula. The prechordal plate is Lim1 positive in A-B'. (C,D) Late gastrulae of G. riobambae. (C) Late-gastrula in whole mount. An image of this embryo at higher magnification was published (del Pino et al., 2007). (D) Sagittal section of a lategastrula. The dorsal Lim1-positive region may represent the prechordal plate. The drawings outline in black the Lim1 signal; Abbreviations: a, archenteron; $b$, blastopore; cbc, circumblastoporal collar; d, dorsal; dl, dorsal lip; pp, prechordal plate; yp, yolk plug. Scale bars: $500 \mu \mathrm{m}(C) ; 300 \mu \mathrm{m}$ in (A); $200 \mu \mathrm{m}$ in $\left(A^{\prime}, B, B^{\prime}, D\right)$. dorsal blastopore lip, Lim1-positive nuclei formed a belt in the vegetal hemisphere. The area with the highest density of Lim1-positive nuclei was on the presumptive dorsal side (del Pino et al., 2007). Once the blastopore was formed, a belt of Lim1-positive nuclei was detected in the blastopore lip (Fig. 2G), with higher density of the Lim1-signal in the dorsal side (Fig. $2 \mathrm{H}$ ). This pattern was maintained until blastopore closure.

\section{Distribution of Lim1 protein in the gastrula of rapidly developing frogs}

We analyzed the distribution of Lim1 in the gastrula of the rapidly developing embryos of $X$. laevis and $E$. randi (Fig. 3 A,B). In st 12.5 embryos of $X$. laevis, the Lim1 signal was detected in the dorsal mesoderm, with strong expression in the prechordal plate and notochord, as previously detected at the Xlim1 mRNA level (Taira et al., 1992), (Fig. $\left.3 A, A^{\prime}\right)$. The lateral and ventral mesoderm was Lim1negative at this stage, although in earlier embryos Lim1 was distributed in these regions of the mesoderm. Similarly, in E. randi embryos of st 12.5, the Lim1 signal became restricted to the archenteron roof, marking the prechordal plate and notochord (Fig. 3 B,B'). The archenteron is partially covered with endoderm in $E$. randi embryos of this stage, and the Lim1-positive prechordal plate is exposed in the archenteron roof (Fig. 3B').

\section{Distribution of Lim1 protein in the gastrula of slow developing frogs}

The protein Lim1 was detected in the prechordal plate of the $C$. machalilla gastrulae. In st 12-12.75 embryos, only the anterior region of the archenteron roof was Lim1-
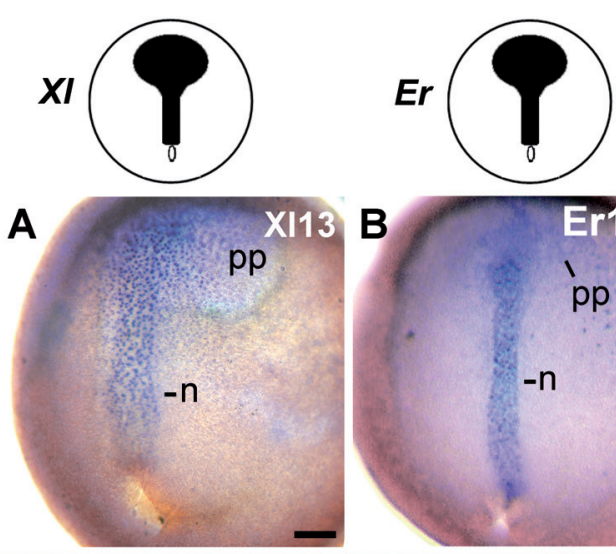
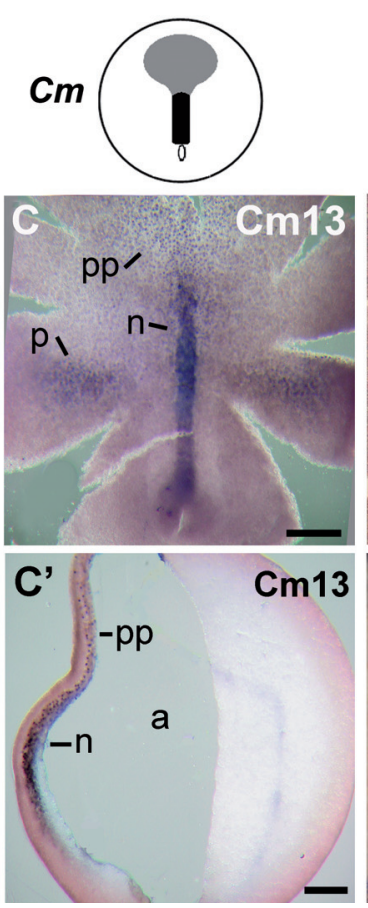
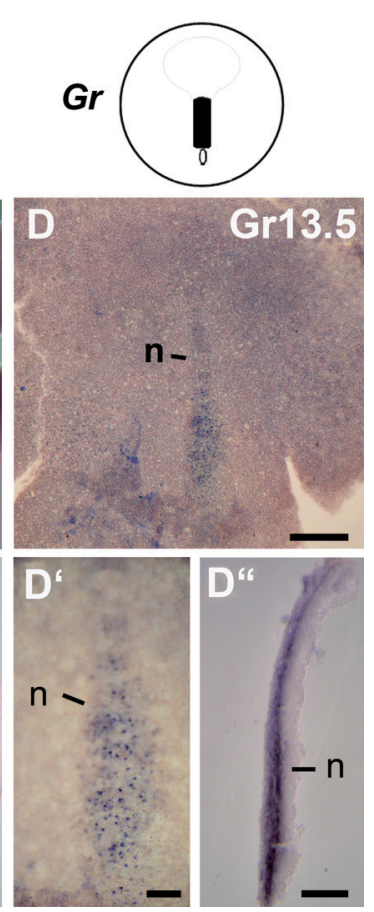
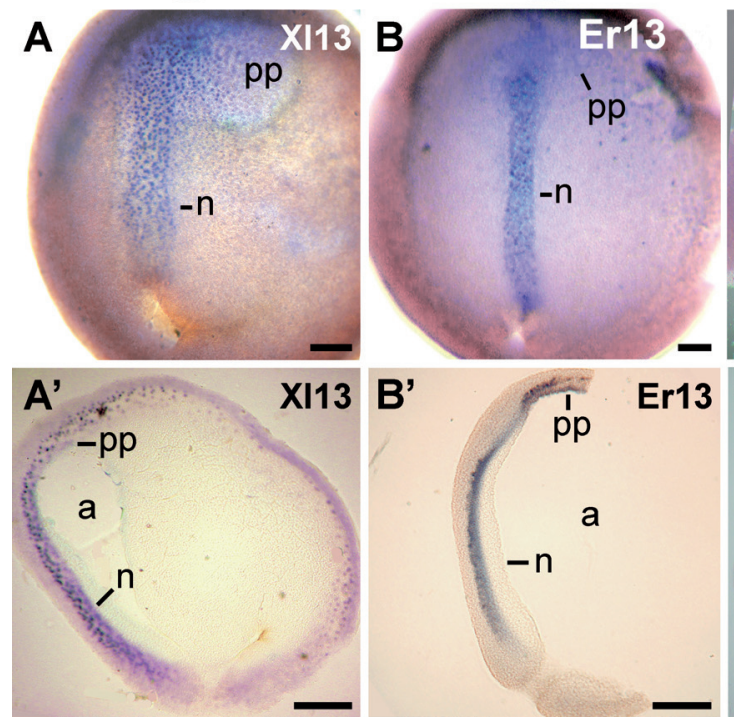

Fig. 5. The notochord and prechordal plate in the late gastrula. $\left(\mathbf{A}, \mathbf{A}^{\prime}\right) X$. laevis. (A) Late gastrula in whole mount. (A') Sagittal section through the notochord and prechordal plate. (B, $\mathbf{B}^{\prime}$ ) E. randi. (B) Late gastrula in whole mount. (B') Sagittal section through the notochord and prechordal plate. (C,C') C. machalilla. (C) Late gastrula in whole mount. (C') Sagittal section through the notochord and prechordal plate. (D-D") G. riobambae. (D) Embryo in whole mount. (D') Higher magnification of the notochord from the embryo shown in D. (D") Sagittal section through the notochord from the embryo shown in D. The drawings outline the Lim1 signal in black. The down regulation of the protein Lim1 in the prechordal plate of C. machalilla is shown in gray. Abbreviations: a, archenteron; $n$, notochord; $p$, pronephros; pp, prechordal plate. Scale bars: $400 \mu \mathrm{m}(C) ; 300 \mu \mathrm{m}\left(D_{,} D^{\prime \prime}\right) ; 200 \mu \mathrm{m}\left(A^{\prime}, B^{\prime}, C^{\prime}\right) ; 100 \mu m\left(A, B, D^{\prime}\right)$. 

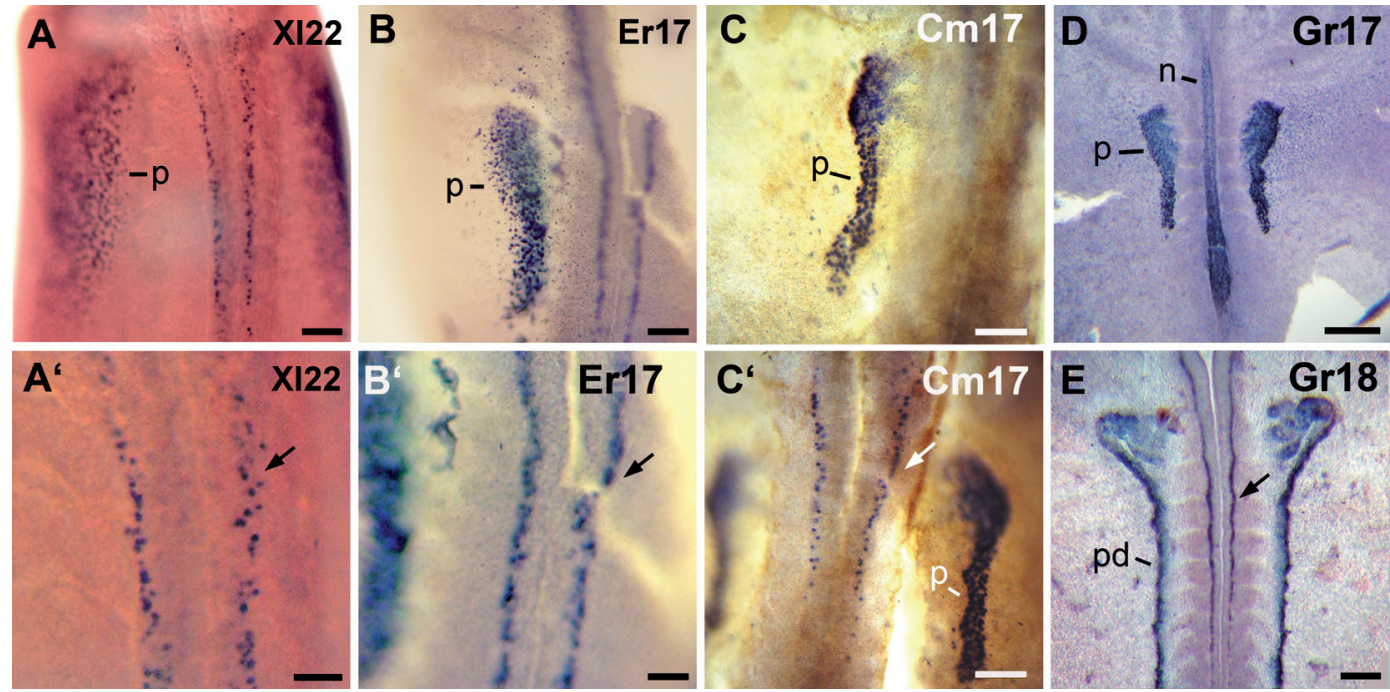

Fig. 6. Lim1 in the pronephros and cns. $\left(\mathbf{A}, \mathbf{A}^{\prime}\right) X$. laevis neurula. (A) The image is focused in the pronephros. (A') Lim1-positive cells of the cns from the embryo in (A). (B, B') E. randi neurula. (B) Image focused in the pronephros. (B') Lim1-positive cells of the cns from the embryo in (B). (C, $\left.\mathbf{C}^{\prime}\right) \mathbf{C}$. machalilla neurula. (C) Image focused in the pronephros. (C') Lim 1 positive cells of the cns from the embryo in (C). (D,E) G. riobambae neurulae. (D) Lim1 staining of the pronephros and notochord. Cells of the cns were not detected at this stage in G. riobambae embryos. (E) Pronephros and cns Lim1-positive cells from a more advanced embryo. Arrows in $A^{\prime}, B^{\prime}, C^{\prime}$ and E indicate the Lim1-positive cells of the cns. Abbreviations: $n$, notochord; $p$, pronephros, pd, pronephric duct. Scale bars: $400 \mu \mathrm{m}(D) ; 200 \mu \mathrm{m}(E) ; 100 \mu \mathrm{m}\left(A, B, C, C^{\prime}\right)$ and $50 \mu \mathrm{m}\left(A^{\prime}, B^{\prime}\right)$.

positive, marking the prechordal plate (Fig. 4 A,B). In contrast, the blastopore lip region was Lim1-negative (Fig. 4 A',B'). The notochord was not detected during gastrulation in embryos of $C$. machalilla (Fig. 4 A', B'), as it develops after closure of the blastopore (Benítez and del Pino, 2002).

In G. riobambae embryos of st $12.75-13$, a belt of nuclei around the blastopore lip was Lim1-positive, with a higher density in the dorsal region (Fig. 4 C,D). This pattern resembled expression in the dorsal blastopore lip and prospective lateral and ventral mesoderm of st 10.5 embryos of $X$. laevis (Fig. 2 A,B). The prechordal plate was not clearly recognized in G. riobambae embryos. It is likely that the prechordal plate may locate toward the dorsal side, in the vicinity of the blastopore (Fig. 4 C,D), as Lim-1 positive cells remain in the blastopore lip area during gastrulation (Fig. 4D). Analyses of other prechordal plate markers, such as gsc, are needed to clearly determine the location of the prechordal plate in G. riobambae embryos. In G. riobambae and $C$. machalilla, elongation of the notochord is delayed until after blastopore closure. In contrast, the notochord elongated during gastrulation in embryos of $X$. laevis and $E$. randi (Fig. 3 $A, B)$.

\section{Distribution of Lim1 protein in the late gastrula and older embryos}

Lim1-protein was detected in the prechordal plate and notochord in the late gastrula of $X$. laevis (Fig. 5 A, A'), E. randi (Fig. 5 B, B'), and C. machalilla (Fig. 5 C, C'). In contrast, in st 13 embryos of $G$. riobambae, the notochord was not yet visible, and the Lim1 signal was restricted to the small embryonic disk (Fig. 4 C,D). In slightly older embryos of $G$. riobambae, the notochord elongated (Fig. 5D), and Lim1-positive nuclei became restricted to the notochord. The prechordal plate was not observed, as by the time of notochord elongation, the Lim1-signal disappeared from other regions of the embryonic disk (Fig. 5 D',D').

The protein Lim1 was detected in the pronephros, and in some cells of the cns in $X$. laevis (Fig. 6A-A'), E. randi (Fig. 6 B,B'), C. machalilla (Fig. 6 C,C'), and G. riobambae (Fig. 6 D,E) advanced embryos. This pattern is comparable with that of Xlim1 mRNA expression in embryos of $X$. laevis (Taira et al., 1994a). Embryos of $G$. riobambae had a different timing of development; thus, the Lim1-signal was absent from cells of the cns in neurula stage embryos, and was detected at a later stage, in contrast with embryos of other frogs (Fig. $6 A^{\prime}, B^{\prime}, C^{\prime}, E$ ).

\section{Discussion}

\section{Expression of the Lim1 gene is conserved}

Lim1-protein distribution in the blastopore lip, notochord, pronephros, and cns cells in embryos of different frogs (Fig. 5,6 ) is equivalent with the expression of $X \lim 1 \mathrm{mRNA}$ in $X$. laevis embryos (Taira et al., 1994a). The observed similarities may derive from conserved Lim1 developmental pathways in different frogs. Expression of Lim1 in the notochord, pronephros, and cells of the cns occurs also in rat and mouse embryos, indicating that gene Lim1, and its molecular interactions are conserved in the development of different vertebrates (Karavanov et al., 1996).

\section{Organizer development in different frogs}

The expression of $X \lim 1$ in the blastopore lip of $X$. laevis embryos marks the prospective axial, lateral, and ventral mesoderm (Taira et al., 1992, 1994a). A similar distribution of Lim1 protein occurs in the early gastrula of other frogs (Fig. 2). Therefore, it is likely that Lim1 protein marks, not only the dorsal, but also the lateral and ventral prospective mesoderm in the early gastrula of $X$. laevis, E. randi, $C$. machalilla and G. riobambae. Duplication of the dorsal axis by transplantation of the dorsal blastopore lip, and by ectopic expression of Lim1 in the ventral side should be tested experimentally in embryos of these frogs. In addition, analyses of cell fate, and of the morphogenetic movements of ce in embryos of different frogs are needed to complement this study.

The expression of Xlim1 in the prechordal plate and notochord reveals that the head and trunk organizers are juxtaposed in the mid-gastrula of $X$. laevis (Fig. 3 A,A'; 7 A,B), (Taira et al., 1997) and $E$. randi (Fig. $\left.3 \mathrm{~B}, \mathrm{~B}^{\prime}\right)$. In contrast, only the prechordal plate developed in embryos of $C$. machalilla during gastrulation (Fig. 
7C). By the time of blastopore closure, the Lim1 signal weakened in the prechordal plate (signaled in gray in Fig. 7C), whereas the newly elongated notochord became strongly positive for Lim1 (Fig. 7C). The separation of head and trunk organizers observed in C. machalilla embryos may relate to the slow rate of development of this frog.

In contrast with $X \lim 1$, the gene $X B r a$ is not expressed in the prechordal plate. Xbra mRNA is expressed in the mesoderm of the trunk, and notochord of the $X$. laevis gastrula (Conlon et al., 2001; Gont et al., 1993; Smith et al., 1991), (Fig. 7B). In the slow

A

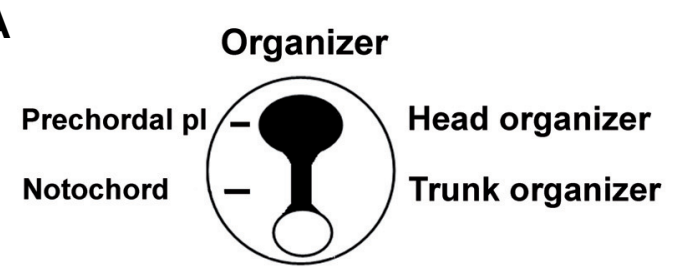

B

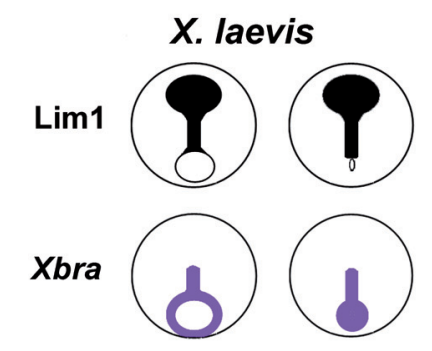

C

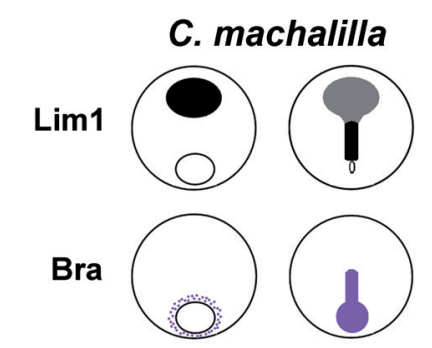

D

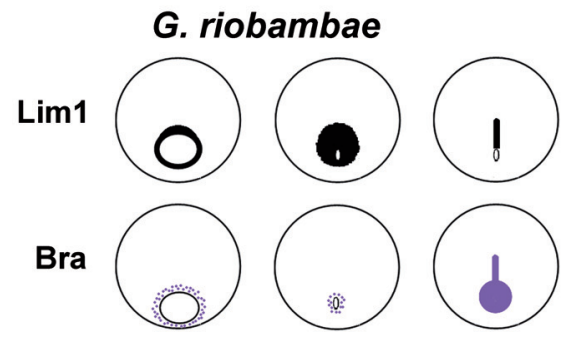

Fig. 7. Comparison of Lim1 and Bra expression in the gastrula. The Lim1 signal is shown in black, and the Bra signal in purple. (A) Schematic view of the X. laevis head and trunk organizer from classical transplantation experiments (reviewed in Saxén, 1989), which correspond to the developing notochord and prechordal plate (redrawn from Taira et al., 1997). (B) Lim1 and Bra expression in X. laevis. (C) Lim1 and Bra expression in C. machalilla. (D) Lim 1 and Bra expression in G. riobambae. The pattern differences found in these frogs are discussed in the text. See the following articles for the pattern of Bra expression in different frogs (Smith et al., 1991; Gontet al., 1993; del Pino, 1996; Benítez and del Pino, 2002). Abbreviation: pl, plate. developing embryos of $C$. machalilla, and G. riobambae, two Brasignals developed around the blastopore (Fig. 7 C,D). The early signal was superficial around the blastopore (indicated by dots in Fig. 7 C,D), and may associate with blastopore closure, as in $X$. laevis and other organisms (Technau, 2001; Marcellini et al., 2003). A late Bra-signal was detected in deep regions of embryos with a closed blastopore, marking the notochord and the mesoderm of the trunk (Benítez and del Pino, 2002; del Pino, 1996), (Fig. $7 \mathrm{C}, \mathrm{D}$ ). The observed variation indicates that aspects of dorsalization, such as ce, can be shifted to the end of gastrulation, and emphasize the modular character of frog gastrulation (Ewald et al., 2004; Moya et al., 2007). The delayed pattern of notochord elongation detected in slow developing frogs by the expression of Lim1 and Bra may associate with delay in the onset of the planar cell polarity pathway and ce, as in $X$. laevis embryos these processes are downstream of XBra (Conlon and Smith, 1999; Kwan and Kirschner, 2003; Smith, 1999; Tada and Smith, 2000).

The head and trunk organizers of $X$. laevis embryos differ in cell behavior and gene expression. Cell migration is confined to the prechordal plate and to the anterior neural plate, whereas ce directs the formation of the notochord and patterning of the trunk (Taira et al., 1994a; Winklbauer, 1990; Hukriede et al., 2003; Kwan and Kirschner, 2003). These cellular behaviors are associated with different patterns of gene expression in the head and trunk organizers (reviewed in de Robertis, 2006; Niehrs, 2004). Similarly, different mechanisms may control the separate occurrence of head and trunk organizers in embryos of frogs with slow development. Our analysis suggests that the dorsal lip of the blastopore has a different schedule of gene expression in frogs that develop more slowly than $X$. laevis.

\section{Materials and Methods}

\section{Culture of embryos and staging}

Embryos were maintained as previously described (Benítez and del Pino, 2002; del Pino et al., 2004, 2007). Embryos of E. randiwere donated by L. A. Coloma and collaborators. Gastrulae of all frogs were staged according to the $X$. laevis normal table of stages until st 14 (Nieuwkoop and Faber, 1994). After st. 14, the C. machalilla and Engystomops tables of stages were used (del Pino et al., 2004; Romero-Carvajal et al., 2009). Embryos of $G$. riobambae were staged according to a general staging table for anurans (Gosner, 1960). The collection localities are given in del Pino et al. (2007). Some adults of G. riobambae were purchased from Hyla, Quito, Ecuador. The authorization 016-IC-FAU-DNBAP-MA from the Ministry of the Environment, Ecuador allowed the collection of frogs.

\section{Preparation and characterization of anti-Lim1 antibody}

The conserved C-terminal region (amino acids 275 - 403; Swissprot accession no. P29674) of the $X$. laevis homeodomain protein Lim1 was fused to glutathione S-transferase (GST-Lim1C), and injected into rabbits for the production of antibodies. Anti-Lim1 antibody was affinity-purified with a GST-Lim1C coupled to CNBr-activated Sepharose 4B column. Immunoblot analysis was performed with in vitro translated products and embryonic lysates. The Xlim1 protein and its $\mathrm{N}$-terminal Lim domaindeleted construct, $X \lim 1 \Delta \mathrm{NK}$ (Karavanov et al., 1996), were synthesized using the reticulocyte lysate TNT system (Promega) with no DNA or plasmid DNA (1 pg DNA per reaction). Embryonic lysates were prepared at the early gastrula stage from uninjected embryos or from embryos that were injected at the two cell stage with $100 \mathrm{pg}$ of $X \lim 1 \mathrm{mRNA}$ per embryo.

\section{Whole mount immunostaining and in situ hybridization}

The immunostaining procedure was modified for frog embryos of large 
size (Hemmati-Brivanlou and Harland, 1989; Benítez and del Pino, 2002). The embryos were fixed in MEMFA buffer (Harland, 1991) for $2.5 \mathrm{hr}$ at room temperature and stored in methanol at $-20^{\circ} \mathrm{C}$ until processing. Fixed embryos were equilibrated in dimethyl sulfoxide and methanol (1:1) for 24 hrs at $-20^{\circ} \mathrm{C}$, and incubated for $30 \mathrm{~min}$ in $10 \%$ Triton X-100 at room temperature. Nonfat milk (5\%) was added to the blocking reagent and antibody dilutions to prevent the non-specific union of the antibodies. Embryos were incubated for $2-3$ days at $4^{\circ} \mathrm{C}$ with a 1:250 dilution of the anti-Lim1 antibody. The secondary antibody was sheep anti-rabbit IgG conjugated to alkaline phosphatase (Boehringer Mannheim $\mathrm{GmbH}$, Mannheim, Germany). Embryos were incubated overnight with a 1:500 dilution of the secondary antibody. Embryos were washed extensively over a period of about 12 to $24 \mathrm{hr}$ at $4^{\circ} \mathrm{C}$ after incubation with each antibody. The presence of the bound secondary antibody was detected with NBT/BCIP color reaction. After immunostaining, embryos were post fixed in Smith's solution B (200 ml formaldehyde $37 \%, 50 \mathrm{ml}$ glacial acetic acid, and $750 \mathrm{ml} \mathrm{H}_{2} \mathrm{O}$ ) to stabilize the color reaction. Some embryos were bleached in $1 \% \mathrm{H}_{2} \mathrm{O}_{2}, 5 \%$ formamide and $0.5 \times$ standard saline citrate for $1 \mathrm{hr}$ (Mayor et al., 1995).

Thick sections of immunostained embryos were produced with a Vibratome 1000 (Technical Products International, Inc., St. Louis, MO) as previously described (Moya et al., 2007). The sections were dehydrated in methanol and transferred to benzyl benzoate/benzyl alcohol 2:1 and mounted. To detect cell nuclei, some embryos were counter-stained with Hoechst 33258 (Sigma-Aldrich, St. Louis, MO, USA), mounted in glycerol, and examined with fluorescent optics.

Whole mount in situ hybridization was performed according to Harland (1991). The Xlim1 digoxigenin RNA probe was previously described (Taira et al., 1992).

\section{Acknowledgments}

We thank L. A. Coloma, S. Ron, and other members of the Herpetology laboratory of the Pontificia Universidad Católica del Ecuador for the donation of E. randi embryos; L. E. López for frog collection; N. Sáenz, and I. Moya for help with immunostaining and embryo processing. We acknowledge and thank O. D. Pérez, and P. Montenegro-Larrea, for frog care and helpful discussions, and $C$. Keil for language revision. We thank I. B. Dawid for critical discussions. Grant sponsors: Pontificia Universidad Católica del Ecuador: 2006, 2007 grants; The Academy for the Developing World (TWAS): Grant 07-017 LDC/BIO/LA-UNESCO FR 3240144821; Global COE Program (Integrative Life Science Based on the Study of Biosignaling Mechanisms), MEXT, Japan (N. Sudou).

\section{References}

BENíTEZ, M.S. and DEL PINO, E.M. (2002). The expression of Brachyury during development of the dendrobatid frog Colostethus machalilla. Dev. Dyn. 225: 592-596.

BLITZ, I.L. and CHO, K.W. (1995). Anterior neurectoderm is progressively induced during gastrulation: the role of the Xenopus homeobox gene orthodenticle. Development 121: 993-1004.

CHO, K.W.Y., BLUMBERG, B., STEINBEISSER, H. and DE ROBERTIS, E.M. (1991). Molecular nature of Spemann's organizer: the role of the Xenopus homeobox gene goosecoid. Cell 67: 1111-1120.

CONLON, F.L. and SMITH, J.C. (1999). Interference with Brachyury function inhibits convergent extension, causes apoptosis, and reveals separate requirements in the FGF and activin signaling pathways. Dev. Biol. 213: 85-100.

CONLON, F.L., FAIRCLOUGH, L., PRICE, B.M., CASEY, E.S. and SMITH, J.C. (2001). Determinants of T box protein specificity. Development 128: 37493758.

DAWID, I.B., BREEN, J.J. and TOYAMA, R. (1998). LIM domains: multiple roles as adapters and functional modifiers in protein interactions. Trends Genet. 14: $156-162$

DE ROBERTIS, E.M. (2006). Spemann's organizer and self-regulation in amphibian embryos. Nat. Rev. Mol. Cell. Biol. 7: 296-302.
DEL PINO, E.M. (1996). The expression of Brachyury (T) during gastrulation in the marsupial frog Gastrotheca riobambae. Dev. Biol. 177: 64-72.

DEL PINO, E.M. and ELINSON, R.P. (1983). Gastrulation produces an embryonic disc, a novel developmental pattern for frogs. Nature 306: 589-591.

DEL PINO, E.M., ÁVILA, M.E., PÉREZ, O.D., BENíTEZ, M.S., ALARCÓN, I., NOBOA, V. and MOYA, I.M. (2004). Development of the dendrobatid frog Colostethus machalilla. Int. J. Dev. Biol. 48: 663-670.

DEL PINO, E.M., VENEGAS-FERRÍN, M., ROMERO-CARVAJAL, A., MONTENEGRO-LARREA, P., SÁENZ-PONCE, N., MOYA, I.M., ALARCÓN, I., SUDOU, N., YAMAMOTO, S. and TAIRA, M.A. (2007). Comparative analysis of frog early development. Proc. Natl. Acad. Sci. USA 104: 11882-11888.

EWALD, A.J., PEYROT, S.M., TYSZKA, J.M., FRASER, S.E. and WALLINGFORD J.B. (2004). Regional requirements for Dishevelled signaling during Xenopus gastrulation: separable effects on blastopore closure, mesendoderm internalization and archenteron formation. Development 131: 6195-6209.

GONT, L.K., STEINBEISSER, H., BLUMBERG, B. and DE ROBERTIS, E.M. (1993). Tail formation as a continuation of gastrulation: the multiple cell populations of the Xenopus tailbud derive from the late blastopore lip. Development 119: 991-1104.

GOSNER, K.L. (1960). A simplified table for staging anuran embryos and larvae with notes on identification. Herpetologica 16: 183-190.

GRANT, T., FROST, D.R., CALDWELL, J.P., GAGLIARDO, R., HADDAD, C.F.B., KOK, P.J.R., MEANS, D.B., NOONAN, B.P., SCHARGEL, W.E. and WHEELER, W.C. (2006). Phylogenetic systematics of dart-poison frogs and their relatives (Amphibia: Athesphatanura: Dendrobatidae). Bull. Am. Mus. Nat. History 299: $1-262$.

HARLAND, R.M. (1991). In situ hybridization: an improved whole-mount method for Xenopus embryos. Methods Cell. Biol. 36: 685-695.

HEMMATI-BRIVANLOU, A. and HARLAND, R.M. (1989). Expression of engrailedrelated protein is induced in the anterior neural ectoderm of early Xenopus embryos. Development 106: 611-617.

HOBERT, O. and WESTPHAL, H. (2000). Functions of LIM-homeobox genes Trends Genet. 16: 75-83.

HUKRIEDE, N.A., TSANG, T.E., HABAS, R., KHOO, P.L., STEINER, K., WEEKS D.L., TAM, P.P. and DAWID, I.B. (2003). Conserved requirement of Lim1 function for cell movements during gastrulation. Dev. Cell. 4: 83-94.

KARAVANOV, A.A., SAINT-JEANNET, J.P., KARAVANOVA, I., TAIRA, M. and DAWID, I.B. (1996). The LIM homeodomain protein Lim-1 is widely expressed in neural, neural crest and mesoderm derivatives in vertebrate development. Int. J. Dev. Biol. 40: 453-461.

KELLER, R. (1975). Vital dye mapping of the gastrula and neurula of Xenopus laevis. I. Prospective areas and morphogenetic movements of the superficial layer. Dev. Biol. 42: 222-241.

KELLER, R. (1976). Vital dye mapping of the gastrula and neurula of Xenopus laevis. II. Prospective areas and morphogenetic movements of the deep layer. Dev. Biol. 51: 118-137.

KELLER, R. and SHOOK, D. (2004). Gastrulation in amphibians. In Gastrulation from Cells to Embryo (Ed. C.D. Stern). Cold Spring Harbor, Cold Spring Harbor Laboratory Press. pp. 171-203.

KWAN, K.M. and KIRSCHNER, M.W. (2003). Xbra functions as a switch between cell migration and convergent extension in the Xenopus gastrula. Development 130: 1961-1972

MARCELLINI, S., TECHNAU, U., SMITH, J.C. and LEMAIRE, P. (2003). Evolution of Brachyury proteins: identification of a novel regulatory domain conserved within Bilateria. Dev. Biol. 260: 352-361.

MAYOR, R., MORGAN, R. and SARGENT, M.G. (1995). Induction of the prospective neural crest of Xenopus. Development 121: 767-777.

MOYA, I.M., ALARCÓN, I. and DEL PINO, E.M. (2007). Gastrulation of Gastrotheca riobambae in comparison with other frogs. Dev Biol 304: 467-478.

NIEHRS, C. (2004). Regionally specific induction by the Spemann-Mangold organizer. Nature Rev. Genetics 5: 425-434.

NIEUWKOOP, P.D. and FABER, J. (1994). Normal Table of Xenopus laevis (Daudin). New York, Garland Publishing. 252 p.

PANNESE, M., POLO, C., ANDREAZZOLI, M., VIGNALI, R., KABLAR, B. BARSACCHI, G. and BONCINELLI, E. (1995). The Xenopus homologue of Otx2 
is a maternal homeobox gene that demarcates and specifies anterior body regions. Development 121: 707-720.

ROMERO-CARVAJAL, A., SÁENZ-PONCE, N., VENEGAS-FERRÍN, M., ALMEIDAREINOSO, D., LEE, C., BOND, J., RYAN, M.J., WALLINGFORD, J.B. and DEL PINO, E.M. (2009). Embryogenesis and laboratory maintenance of the foamnesting Túngara frogs, genus Engystomops (= Physalaemus). Dev. Dyn. 238: 1444-1454.

SAXÉN, L. (1989). Neural induction. Int J Dev Biol 33: 21-48.

SMITH, J. (1999). T-box genes: What they do and how they do it. Trends Genet. 15: 154-158.

SMITH, J.C., PRICE, B.M.J., GREEN, J.B.A., WEIGEL, D. and HERRMANN, B.G. (1991). Expression of a Xenopus homolog of Brachyury $(T)$ is an immediateearly response to mesoderm induction. Cell 67: 79-87.

TADA, M. and SMITH, J.C. (2000). Xwnt11 is a target of Xenopus Brachyury: regulation of gastrulation movements via Dishevelled, but not through the canonical Wnt pathway. Development 127: 2227-2238.

TAIRA, M., JAMRICH, M., GOOD, P.J. and DAWID, I.B. (1992). The LIM domain- containing homeo box gene Xlim-1 is expressed specifically in the organizer region of Xenopus gastrula embryos. Genes Dev. 6: 356-366.

TAIRA, M., OTANI, H., JAMRICH, M. and DAWID, I.B. (1994a). Expression of the LIM class homeobox gene Xlim-1 in pronephros and cns cell lineages of Xenopus embryos is affected by retinoic acid and exogastrulation. Development 120: 1525-1536.

TAIRA, M., OTANI, H., SAINT-JEANNET, J.P. and DAWID, I.B. (1994b). Role of the LIM class homeodomain protein Xlim-1 in neural and muscle induction by the Spemann organizer in Xenopus. Nature 372: 677-679.

TAIRA, M., SAINT-JEANNET, J.P. and DAWID, I.B. (1997). Role of the Xlim-1 and $X$ bra genes in anteroposterior patterning of neural tissue by the head and trunk organizer. Proc. Natl. Acad. Sci. USA 94: 895-900.

TECHNAU, U. (2001). Brachyury, the blastopore and the evolution of the mesoderm. BioEssays 23: 788-794.

WINKLBAUER, R. (1990). Mesodermal cell migration during Xenopus gastrulation. Dev. Biol.142: 155-168.

\section{Further Related Reading, published previously in the Int. J. Dev. Biol.}

See our recent Special Issue Epigenetics \& Development edited by Saadi Khochbin and Stefan Nonchev at: http://www.ijdb.ehu.es/web/contents.php?vol=53\&issue=2-3

The N-terminus zinc finger domain of Xenopus SIP1 is important for neural induction, but not for suppression of Xbra expression

Kazuhiro R. Nitta, Shuji Takahashi, Yoshikazu Haramoto, Masakazu Fukuda, Kousuke Tanegashima, Yasuko Onuma and Makoto Asashima

Int. J. Dev. Biol. (2007) 51: 321-325

Development of the dendrobatid frog Colostethus machalilla

Eugenia M. Del Pino, María-Eugenia Ávila, Oscar D. Pérez, María-Soledad Benítez, Ingrid Alarcón, Vanessa Noboa and Iván M. Moya

Int. J. Dev. Biol. (2004) 48: 663-670

The Spemann-Mangold organizer: the control of fate specification and morphogenetic rearrangements during gastrulation in Xenopus T Bouwmeester Int. J. Dev. Biol. (2001) 45: 251-258

Dickkopf1 and the Spemann-Mangold head organizer C Niehrs, O Kazanskaya, W Wu and A Glinka Int. J. Dev. Biol. (2001) 45: 237-240

A study of Xlim1 function in the Spemann-Mangold organizer L Kodjabachian, A A Karavanov, H Hikasa, N A Hukriede, T Aoki, M Taira and I B Dawid

Int. J. Dev. Biol. (2001) 45: 209-218

5 yr ISI Impact Factor $(2008)=3.271$

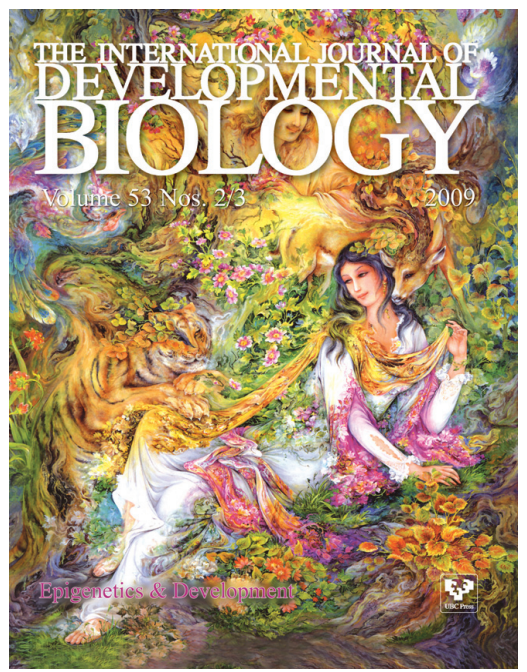

